\title{
Effects of repeated hypoxic shocks on growth and metabolism of turbot juveniles
}

\author{
Jeannine Person-Le Ruyet*, Anne Lacut, Nicolas Le Bayon, Annick Le Roux, \\ Karine Pichavant, Loïc Quéméner
}

Ifremer, centre de Brest, département ressources aquacoles, laboratoire adaptation, reproduction et nutrition, BP 70, 29280 Plouzané, France

Received 14 August 2002; accepted 24 October 2002

\begin{abstract}
Turbot juveniles ( $45 \mathrm{~g})$ were exposed for $41 \mathrm{~d}\left(17^{\circ} \mathrm{C}, 34 \%\right.$ o salinity) to constant normoxic (100-100\% air saturation, 100-100) or moderate hypoxic (75-75\% air saturation, 75-75) conditions and to repeated hypoxic shocks (20\% saturation for $1 \mathrm{~h}, 5 \mathrm{~d}$ per week) from normoxic (100-20\% air saturation, 100-20) or moderate hypoxic (75-20\% air saturation, 75-20) conditions. A normoxic group was feed restricted (100-FR). Mass increase of 100-100 and 75-75 groups fed to satiation was not significantly different. In comparison, it was significantly lower in the 100-20 and 75-20 groups (NS between the two hypoxic shocks groups). Intermediate results were obtained in the 100-100-FR group. The lowest mass increase under hypoxic shocks was explained by a significant decrease in both feed intake and food conversion efficiency (FCE). FCE was lower in the two hypoxic groups, but only the 75-20 group was significantly different from all the other groups. There was no sign of stress and no change in the physiological status of fish in any group. When challenged, pre-conditioning of turbot to regular hypoxic shocks extended survival time, slightly but significantly, for $50 \%$ of the population. It was $8 \mathrm{~h}$ longer in starved than in fed fish. When reared for 1 year in normoxic water, the growth rate of post-challenged survivors was dependent on pre-conditioning: day 0-375 specific growth rate was significantly higher in the two groups acclimated to repeated hypoxic shocks. In the second experiment, it was shown that exposure to $20 \%$ air saturation for $12 \mathrm{~h}$ led to major physiological changes within $4 \mathrm{~h}$ : a significant decrease in plasma total $\mathrm{CO}_{2}$ and increase in plasma lactate contributing in maintaining blood $\mathrm{pH}$ stable, and a significant increase in osmolarity and chloride concentration. When returned to normoxic water, the recovery capacity of the fish was high: plasma osmolarity and total $\mathrm{CO}_{2}$ returned to pre-exposure levels within $1 \mathrm{~h}$. The results are discussed in terms of turbot capacity to cope with repeated hypoxic shocks and to acclimate.
\end{abstract}

(C) 2003 Éditions scientifiques et médicales Elsevier SAS and Ifremer/IRD/Inra/Cemagref. All rights reserved.

\section{Résumé}

Effets de chocs hypoxiques répétés sur la croissance et le métabolisme du turbot juvénile. Des turbots (45 g) ont été élévés pendant 41 jours $\left(17^{\circ} \mathrm{C}\right.$, et 34 salinité) en normoxie (100-100\% de la saturation) ou hypoxie modérée (75-75), ou soumis à des chocs hypoxiques de $20 \%$ de la saturation pendant une heure 5 fois par semaine (100-20 et 75-20). Un lot en normoxie reçoit la ration alimentaire du lot 100-20 (100-R). La croissance pondérale n'a pas été perturbée par l'hypoxie modérée à niveau constant mais l'a été par les chocs hypoxiques répétés. La baisse de croissance observée résulte d'un effet cumulé d'une baisse de l'appétit et d'une diminution de l'efficacité alimentaire (lot 75-20 significativement différent des autres lots). Aucune modification de l'état physiologique n'a été mise en évidence (absence de stress). Une mise à l'épreuve en fin d'expérience ( $20 \%$ de la saturation) a montré qu'un préconditionnement à différentes conditions d'oxygénation a un effet bénéfique faible mais significatif sur le temps de survie de $50 \%$ de la population. Chez des poissons à jeun il surpasse de $8 \mathrm{~h}$ celui des poissons nourris. Le taux de croissance spécifique des survivants à cette épreuve est de même affecté par l'histoire des poissons. Sur une période d'un an, il est significativement supérieur chez les lots ayant subi des chocs hypoxiques que chez des lots maintenus en conditions d'oxygénation stables. Une seconde expérience a montré que face à une hypoxie sévère prolongée (20\% de la saturation) le turbot met en place divers processus d'ordre respiratoire et métabolique : baisse $\mathrm{du} \mathrm{CO}_{2}$ total plasmatique et augmentation du lactate contribuant à stabiliser le pH, augmentation de l'osmolarité et des chlorures. Lors du retour à la normoxie, la capacité de récupération est importante : retour du $\mathrm{CO}_{2}$ total et de l'osmolarité du plasma aux niveaux initiaux en une heure. La capacité du turbot à s'adapter à des chocs hypoxiques répétés et à récupérer sont discutés.

\footnotetext{
* Corresponding author.

E-mail address: jperson@ifremer.fr (J. Person-Le Ruyet).
} 
(C) 2003 Éditions scientifiques et médicales Elsevier SAS and Ifremer/IRD/Inra/Cemagref. Tous droits réservés.

Keywords: Hypoxic shock; Growth; Metabolism; Turbot

\section{Introduction}

Fish experience wide fluctuations of oxygen concentrations in their natural environment, mainly in coastal areas, with consequences highly dependent on fish ability to avoid areas of low dissolved oxygen. Behavioural studies have shown that in several fish species, the threshold detection concentration is $1 \mathrm{mg} \mathrm{l}^{-1}$ and the oxygen avoidance concentration is $<35-55 \%$ air saturation within a wide temperature range, $10-30{ }^{\circ} \mathrm{C}$ (Wannamaker and Rice, 2000). Fish reared in sea cages are also exposed to periodic episodes of hypoxic conditions (diel, tidal, seasonal fluctuations) or to chronic oxygen depletion when stocking density becomes excessive, and they are not able to avoid such adverse conditions. In comparison, in land-based systems, especially when oxygen supplementation is used to stabilise $\mathrm{O}_{2}$ concentrations over $90 \%$ air saturation, fish are, in theory, only exposed to diel $\mathrm{O}_{2}$ oscillations related to feeding pattern (Blancheton, 2000), whereas it is a fact that they may be routinely or accidentally exposed to hypoxic shocks occurring either during maintenance processes (cleaning operations) or handling (grading and weighing).

Fish tolerance to stable hypoxic conditions varies between species. In freshwater species, the $\mathrm{O}_{2}$ concentration at which the decrease in growth is observed is $<4-5 \mathrm{mg} \mathrm{l}^{-1}$ in coho salmon (Oncorhynchus kisutch), largemouth bass (Micropterus salmoides) and carp (Cyprinus carpio) and $7 \mathrm{mg} \mathrm{l}^{-1}$ in rainbow trout (Oncorhynchus mykiss) (Brett and Blackburn, 1981; Pedersen, 1987). In juveniles of turbot (Scophthalmus maximus, also called Psetta maxima) and seabass (Dicentrarchus labrax), the threshold $\mathrm{O}_{2}$ concentration for growth is in the range of 5-6 $\mathrm{mg} \mathrm{l}^{-1}$ when fed to satiation and when other environmental conditions are optimal (Pichavant et al., 2000, 2001). In spotted wolffish juveniles (Anarhichas minor), over a 3-month period, the mass increase is $14 \%$ lower at $6 \mathrm{mg} \mathrm{l}^{-1}$ than in a normoxic group $\left(9.6 \mathrm{mg} \mathrm{l}^{-1}\right.$ ) (Foss et al., 2002). Growth decrease is primarily explained by reduced food intake. In turbot and seabass juveniles, there is no change in food conversion efficiency (FCE) and no major physiological disturbances up to $3.5 \mathrm{mg} \mathrm{l}^{-1} \mathrm{O}_{2}$ concentrations; the acute lethal concentration is in the range of $0.75-1 \mathrm{mg}^{-1}$ (Person-Le Ruyet et al., 1991; Pichavant et al., 2001).

The impact of fluctuating ambient $\mathrm{O}_{2}$ concentrations on fish growth performance has been studied very little. In some freshwater species, brook trout (Salvelinus fontinalis), coho salmon and largemouth bass, growth is reported to be more affected by fluctuations of $\mathrm{O}_{2}$ concentrations than by exposure to constant intermediate $\mathrm{O}_{2}$ concentrations (Brett, 1979, review). Adverse effects on the growth of $\mathrm{O}_{2}$ oscillations compared to constant concentrations (6.2-2.8 and
$4.74 \mathrm{mg}^{-1}$, respectively) have recently been demonstrated in juvenile southern flounder (Paralichthys lethostigma) and related respiratory adjustments have been described (Taylor and Miller, 2001). In comparison, growth performances of seabass juveniles are not significantly affected by repetitive $\mathrm{O}_{2}$ oscillations between 6 and $3 \mathrm{mg} \mathrm{l}^{-1} \mathrm{O}_{2}$ concentrations compared to constant $\mathrm{O}_{2}$ concentrations of 6 and $3 \mathrm{mg} \mathrm{l}^{-1}$ (Thetmeyer et al., 1999).

The main objective of the study was to determine the effects on the growth performance and the physiological status of repetitive severe hypoxic shocks in turbot juveniles reared either under sustained moderate hypoxic or under normoxic conditions. At the end of the experiment, fish were challenged to determine whether acclimation occurred in response to repeated hypoxic shocks. Their capacity to survive an additional severe hypoxic shock (i.e. $20 \%$ saturation for $1 \mathrm{~h}, 5 \mathrm{~d}$ per week) and their growth when exposed to normoxic conditions for 1 year were investigated. Short-term physiological responses to highly hypoxic water and turbot recovery capacity were also studied to determine how juvenile turbot adapt to hypoxic shocks.

\section{Materials and methods}

\subsection{Fish and rearing conditions}

Experiments were carried out with 5-month-old hatcheryreared turbot. Graded fish were held for 1 month prior to the start of the experiment in $2 \mathrm{~m}^{3}$ tanks $(2 \times 2 \times 0.5 \mathrm{~m})$ supplied with running water at $17.0 \pm 0.5{ }^{\circ} \mathrm{C}, 34.5 \%$ o salinity and $\mathrm{O}_{2}$ concentration $>85 \%$ air saturation. The photoperiod was maintained at $16 \mathrm{~L}: 8 \mathrm{D}$, and the light intensity was $2 \mathrm{~W} \mathrm{~m}^{-2}$. Fish were fed by hand with a commercial dry pellet (Le Gouessant ${ }^{\circledR}, 3.5 \mathrm{~mm}$ diameter; total protein and crude fat $53 \%$ and $13 \%$ of dry matter, respectively).

After pre-acclimation, the fish were divided into groups of 100 and randomly distributed among 10 tanks: $1 \mathrm{~m}^{2}$ tanks $(1 \times 1 \times 0.3 \mathrm{~m})$ with an effective volume of 3001 . The tanks were supplied with a continuous flow of water, with an exchange rate of $12.51 \mathrm{~min}^{-1}$. Fish were then allowed to acclimate to the feeding and rearing conditions for 2 weeks. Environmental conditions were similar to those of the preacclimation period, except that fish were held under normoxic conditions $\left(\mathrm{O}_{2}\right.$ concentration of outlet water, $7.6 \mathrm{mg} \mathrm{l}^{-1}$ ) using oxygen supplementation. They were fed by hand to apparent satiation (feed intake (FI) was assumed to equal feed provision) twice a day, at $10.00 \mathrm{~h}$ (morning meal) and $16.00 \mathrm{~h}$ (evening meal), with the same commercial dry pellet as that used during pre-acclimation. 


\subsection{Experimental design}

\subsubsection{Long-term experiment}

After acclimation, a 41-d experiment was carried out using duplicate groups of 100 turbot (initial weight $45 \pm$ $0.5 \mathrm{~g}$, mean \pm S.E.) exposed to the following five experimental conditions:

- Two groups of fish were reared under constant $\mathrm{O}_{2}$ concentrations and fed to satiation. One group (100-100 group) was maintained in a normoxic condition (7.6 $\mathrm{mg} \mathrm{O}_{2} \mathrm{l}^{-1}, 100 \%$ air saturation) and another group (75-75 group) was changed to a moderate hypoxic condition (5.7 $\mathrm{mg} \mathrm{O}_{2} \mathrm{l}^{-1}, 75 \%$ air saturation) within $4 \mathrm{~h}$.

- Two groups reared either in normoxic or in moderate hypoxic water were exposed to $20 \%$ air saturation for $1 \mathrm{~h}, 5 \mathrm{~d}$ per week, and fed to satiation. The $\mathrm{O}_{2-}$ concentration range was $7.4-1.5 \mathrm{mg}^{-1}$ in the $100-20$ group and 6.0-1.5 $\mathrm{mg} \mathrm{l}^{-1}$ in the 75-20 group.

- One group was maintained under a constant normoxic condition and fed restricted rations (100-FR group). The daily feed restricted ration was equal to the mass of food ingested per fish of the 100-20 group.

The hypoxic tanks were supplied with $\mathrm{O}_{2}$ deprived water obtained by the injection of nitrogen to remove the desired amount of oxygen using an oxygen depletion system described by Pichavant et al. (2000). Oscillating $\mathrm{O}_{2}$ concentrations were created by manipulating the water supply without changing the water flow rate: the initial water supply $(100 \%$ or $75 \%$ air saturation water) was abruptly switched for $20 \%$ air saturation water. $\mathrm{O}_{2}$ concentration was decreased from $100 \%$ or $75 \%$ air saturation to $20 \%$ air saturation within $1 \mathrm{~h}$, then maintained at $20 \%$ air saturation for $45 \mathrm{~min}$ and finally increased to initial concentrations within 45 min Fig. 1). Over the 6-week experiment, hypoxic shocks were applied at $13.00 \mathrm{~h}$ on Monday, $10.00 \mathrm{~h}$ on Tuesday, $18.00 \mathrm{~h}$ on Wednesday, $16.00 \mathrm{~h}$ on Thursday and $12.00 \mathrm{~h}$ on Friday. They occurred at different time depending on the feeding time (fixed at 10.00 and $16.00 \mathrm{~h}$ ). On sampling and weighing dates, no hypoxic shock was applied to fish. The $\mathrm{O}_{2}$ concen-

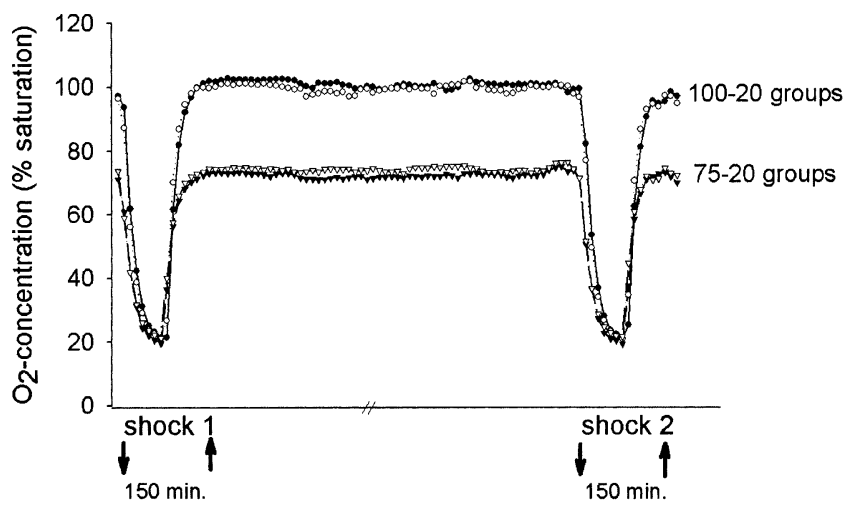

Fig. 1. $\mathrm{O}_{2}$ concentration profile used to simulate hypoxic shocks in normoxic water (from $100 \%$ to $20 \%$ saturation, 100-20 groups) and moderate hypoxic water (from $75 \%$ to $20 \%$ saturation, $75-20$ groups). Air saturation at $17{ }^{\circ} \mathrm{C}$ and $34.5 \%$ salinity was $7.6 \mathrm{mg} \mathrm{l}^{-1} \mathrm{O}_{2}$. Hypoxic shocks were applied five times per week. trations in each tank of the 100-20 and 75-20 groups were monitored when hypoxic shocks were applied (four measurements per hour and per tank) according to a method adapted from Gaumet et al. (1995). Ambient $\mathrm{pH}$ and ammonia were monitored at 5-d intervals. FI was calculated after each meal.

\subsubsection{Challenge tests}

At the end of the long-term experiment, on day 44, fed fish and 24-h-starved fish of each experimental group (except the 100-100-FR group) were challenged to assess the effects of acclimation to repeated hypoxic shock at lethal times. The $4 \times 2$ groups of 50 fish (left after sampling) were exposed to an acute hypoxic stress $\left(\mathrm{O}_{2}\right.$ concentrations, $20 \%$ air saturation) until $50 \%$ mortality was obtained. The desired level of hypoxia was obtained within $1 \mathrm{~h}$ and maintained stable during the course of the test. The recovery capacity of the surviving fish was then tested through a 12-month growth experiment that started 1 month after the survival challenge test. For each initial experimental condition (100-100, $75-75,100-20,75-20$ ), about 30 challenged-fish were individually tagged (Fish Eagle ${ }^{\circledR}$ pit-tag) and gathered in a $2 \mathrm{~m}^{3}$ tank $(2 \times 2 \times 0.5 \mathrm{~m})$. They were held under local natural environmental conditions $\left(9-18{ }^{\circ} \mathrm{C}, \mathrm{O}_{2}\right.$ concentration $>85 \%$ air saturation) for $375 \mathrm{~d}$.

\subsubsection{Short-term experiment}

To test short-term physiological disturbances and fish recovery capacity after an acute hypoxic shock, three batches of 90 turbot $(90 \mathrm{~g})$ from the initial fish population were used. They were previously acclimated to normoxic conditions for 1 week (300 l tank, same environmental conditions as in the previous experiment). One fish group was then abruptly exposed for $12 \mathrm{~h}$ to sustained $\mathrm{O}_{2}$ concentrations of $20 \%$ air saturation, while the second one, maintained in normoxic water, was used as control. In the hypoxic group, eight fish were sampled at start $\left(t_{0}\right)$ and at regular intervals after the onset of hypoxic exposure: 2, 4, 6, 8, 10 and $12 \mathrm{~h}$. In the control group, fish were sampled at $t_{0}, 2,6$ and $12 \mathrm{~h}$. The third fish group was exposed for $6 \mathrm{~h}$ to $20 \% \mathrm{O}_{2}$ saturation, which was changed to normoxic water within less than $1 \mathrm{~h}$. Fish recovery was monitored for $7 \mathrm{~h}$ by sampling eight fish at the end of the hypoxic phase $\left(t_{0}\right)$ and 1,4 and $7 \mathrm{~h}$ later.

\subsection{Parameters studied}

\subsubsection{Long-term experiment}

All fish in each tank were individually weighed to the nearest $0.1 \mathrm{~g}$ at $14-\mathrm{d}$ intervals. Prior to weighing, fish had been starved for $12 \mathrm{~h}$ and anaesthetised (ethylene glycolmonophenyl ether, $0.5 \mathrm{ml} \mathrm{l}^{-1}$ water). The specific growth rate (SGR) was calculated as: $100\left(\ln w_{\mathrm{f}}-\ln w_{\mathrm{i}}\right) \mathrm{d}^{-1}$, where $w_{\mathrm{i}}$ and $w_{\mathrm{f}}$ are the initial and final mean wet body weight, respectively.

As some fish were regularly removed for blood sampling (and not re-used), apparent FCE and daily FI were calculated per sampling period (days 1-13, 14-28, 29-41) as follows: 
FCE: biomass gain per unit feed provided; daily FI: $100 \times$ (feed provided per day per unit biomass).

At intervals (days 2, 6, 13, 28, 41), blood samples were obtained by the puncture of caudal vessels (six fish per tank) for plasma cortisol analysis. Fish were euthanised using ethylene glycol-monophenyl ether $\left(1.3 \mathrm{ml} \mathrm{l}^{-1}\right.$ water $)$ and plasma samples stored at $-20^{\circ} \mathrm{C}$. Plasma cortisol concentrations were measured by a specific radio-immunoassay adapted from Fostier et al. (1982). Blood samples were also taken from six additional fish per tank for other analyses. On all sampling days, blood $\mathrm{pH}$ was determined immediately after blood sampling (Metrohm ${ }^{\circledR} \mathrm{pH}$ meter fitted with a microflow $\mathrm{pH}$ sensor). On days 2 and 41, blood haematocrit was immediately measured (10,000 rpm, $5 \mathrm{~min})$ and samples were taken for total haemoglobin concentration (Sigma Diagnostics enzymatic kit 525) and red blood cell counts (Thoma's haemocytometer). Blood was centrifuged (3500 rpm, $5 \mathrm{~min}$ ), and samples for plasma total $\mathrm{CO}_{2}$ concentrations were taken within $15 \mathrm{~min}$, and then stored at $4{ }^{\circ} \mathrm{C}$ until measurements were made within $6 \mathrm{~h}$, using a Sigma Diagnostics enzymatic kit (132-UV). All other blood analyses were performed on plasma samples that had been stored frozen: osmolarity using an Advanced Instrument Osmometer ${ }^{\circledR}$, chloride by argentimetric titration using a Radiometer CMT10 ${ }^{\circledR}$, sodium and potassium using an Electrolyte Beckman Analyser ${ }^{\circledR}$, and glycaemia and blood lactate using Sigma Diagnostics enzymatic kits (HK 10 and 735-UV, respectively). Blood samples were taken from fish starved for $12 \mathrm{~h}, 68 \mathrm{~h}$ after the last hypoxic shock, except on day 2 (sampling occurred $12 \mathrm{~h}$ after the second hypoxic shock).

The same analytical procedure was used to test for shortterm physiological disturbances and fish recovery capacity.

\subsubsection{Challenge tests}

During survival challenge, the dead fish in each tank were removed and their number counted every $15 \mathrm{~min}$ from the onset of mortality to the end of the test. The death of fish was judged by the cessation of opercular movements and lack of response when prodded. Lethal time for $20 \%$ and $50 \%$ of the population (LT20 and LT50) was estimated from mortality curves. During post-challenge grow-out test, all fish were regularly individually weighed (seven times during the course of the test).

\subsection{Data analysis}

Statistical analyses were conducted using STATISTICA for Windows. All results are expressed as mean \pm S.E. The effects of $\mathrm{O}_{2}$ experimental conditions on growth and blood parameters concentrations were tested using a two-way nested ANOVA, and tanks were considered as nested factors. One-way ANOVA was used for feeding parameters. Significant ANOVA was followed by a post hoc multiple comparison test (the Newman-Keuls test). Differences were considered significant at $P<0.05$.

Survival responses to the challenge test related to oxygen pre-conditioning $\left(\mathrm{O}_{2}\right.$ level and hypoxic shock) versus feed- ing status of fish were compared globally using a stratified survival analysis (STATISTICA) and then separately in fed and starved fish. The normal regression model and the chisquare statistic were used to compare differences between each treatment. Post-shock growth performances related to oxygen pre-conditioning $\left(\mathrm{O}_{2}\right.$ level and hypoxic shock) were tested on individual SGR for each period using a two-way ANOVA. SGR values were previously arcsinus square-root transformed.

\section{Results}

\subsection{Long-term experiment}

The profile of $\mathrm{O}_{2}$ oscillations of 100-20 and 75-20 groups is reported in Fig. 1 Over a 24-h period, $\mathrm{O}_{2}$ concentrations were $90.3 \pm 1.7 \%$ saturation and $67.3 \pm 1.2 \%$ saturation, respectively. Over a 1-week period (with five hypoxic shocks), they averaged $93 \%$ and $69 \%$ saturation. They were slightly higher in the 100-100 and 75-75 groups, 99.5\% \pm $0.4 \%$ and $76.5 \% \pm 0.6 \%$ saturation, respectively, over the entire experimental period $(n=36)$. The mean $\mathrm{O}_{2}$ concentrations of groups with or without hypoxic shocks are considered of similar levels in this study.

Mass increase in turbot kept under constant moderate hypoxic conditions (the 75-75 group) was not significantly different from that of normoxic fish (the 100-100 group) fed to satiation Fig. 2. In fish exposed to hypoxic shocks, it was significantly lower from day 13 , without significant differences between the 100-20 and 75-20 groups. Intermediate mass gains were obtained in the normoxic group that were fed a restricted ration (100-FR); at the end of the experiment, they were significantly different from all other groups, statistical analysis data are reported in Table 1 These results are confirmed by SGR values (Fig. 3a). Day 0-41 SGR was slightly, but not significantly, lower in the 100-20 than in the 100-100-FR groups.

Exposure to repeated hypoxic shocks led to a significant decrease in FI compared to constant concentrations Fig. 3b. It was of the same magnitude in normoxic and moderate hypoxic water. Disturbances in feeding behaviour were related to the timing of hypoxic shock versus feeding timing Fig. 3d. FI was 10\% and 30\% of reference FI when feeding occurred 3 and $4 \mathrm{~h}$, respectively, after the hypoxic shock. There was no change in fish appetite when hypoxic shock was applied $6 \mathrm{~h}$ after feeding time, while during the hypoxic shock, fish failed to feed. Exposure to repetitive hypoxic shock, led to changes in FCE that was dependent on $\mathrm{O}_{2}$ concentrations Fig. 3c. FCE was significantly lower in the 75-20 group than in all the other groups and it was the highest in voluntary fed restricted fish. Under moderate hypoxic conditions, exposure to repeated hypoxic shock led to a $22 \%$ decrease in FCE (the 75-75 and 75-20 groups) and to an $8 \%$ decrease under normoxic conditions (NS differences between the 100-100 and 100-20 groups). It was not significantly different in the 100-20 group and in the 100-FR 


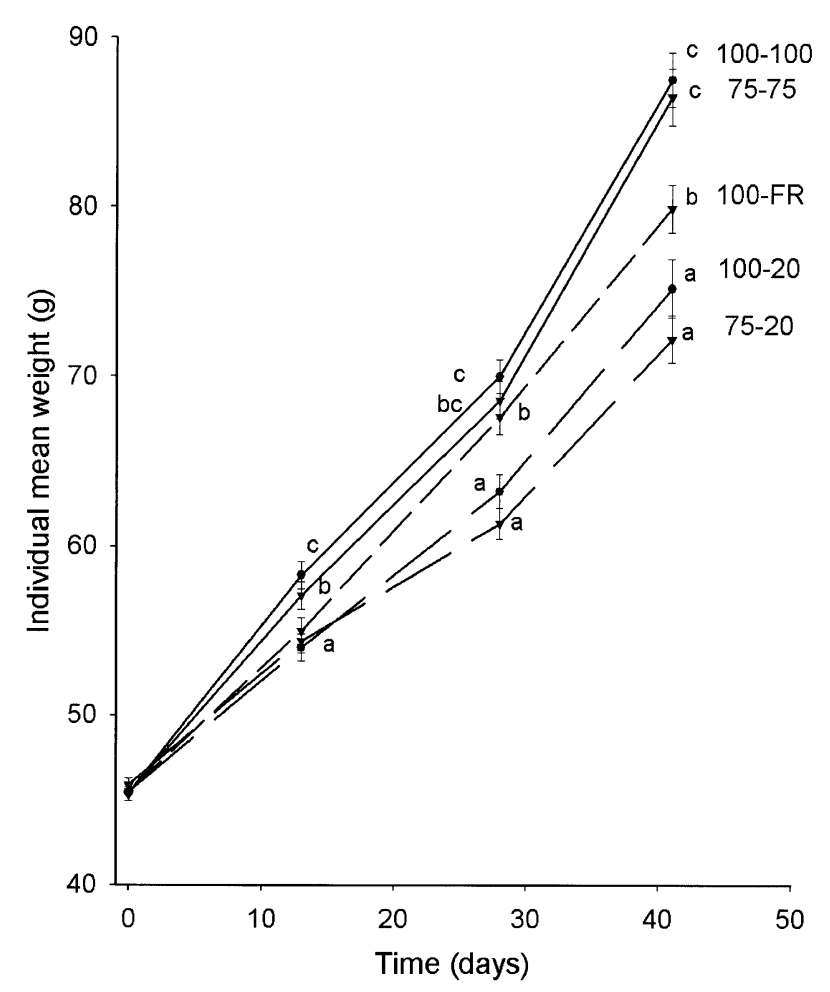

Fig. 2. Changes with time in individual mean weight related to the five oxygen conditions tested: $100-100 \%$ air saturation, sustained normoxic water; $75-75 \%$ air saturation, sustained moderate hypoxic water; 100-20, $\mathrm{O}_{2}$ concentrations fluctuating from $100 \%$ to $20 \%$ air saturation; $75-20, \mathrm{O}_{2}$ concentrations fluctuating from $75 \%$ to $20 \%$ air saturation (see Fig. 1 legend).

group, despite a slight decrease in fish exposed to repeated hypoxic shocks.

Physiological parameters tested were stable for the whole experimental period. The mean values measured on days 2,6 , 13, 28, and 41 are reported in Table 2.

\subsection{Challenge tests}

Estimated LT20 and LT50 of fish exposed to 20\% air saturation are reported in Table 3 Time to mortality was highly affected by the feeding status of the fish (LT50, $P<10^{-6}$ ). It was slightly but significantly affected by $\mathrm{O}_{2}$ pre-conditioning of fish $(P=0.019$ and 0.036 in the starved and fed fish groups, respectively). Survival time $(S)$ is related to hypoxic shock $(x)$ and $\mathrm{O}_{2}$ level $(y)$ by the following equations:

Fed fish: $S=-0.24 x-0.026 y+187$.

Starved fish: $S=-0.19 x-0.66 y+276$.

Table 1

$P$ values from statistical analysis of turbot mean weight related to exposure duration. $S$, significant differences, $P<0.05$; NS, no significant differences

\begin{tabular}{llll}
\hline Effect tested & Day 13 & Day 28 & Day 41 \\
\hline Tank & 0.67 & 0.24 & $0.11 \mathrm{NS}$ \\
$\mathrm{O}_{2}$ conditions & 0.003 & 0.013 & $0.002 \mathrm{~S}$ \\
\hline
\end{tabular}

In starved fish, the differences in survival times were explained by the level of $\mathrm{O}_{2}$ concentrations $(t=2.06)$, while in fed fish, they were explained by the hypoxic shocks $(t=$ 2.56).

The SGRs of fish after the survival challenge test, when held for 1 year in normoxic water, are shown in Fig. 4 Survival was $100 \%$. SGR was significantly higher when fish had been previously exposed to repeated hypoxic shocks, but exclusively during period 1 Table 4). Beyond period 1 (days 0-34), no significant differences were observed between groups with or without hypoxic shocks; for the entire experience, they averaged 0.70 and 0.64 , respectively. SGR growth decrease with time was highly dependent on ambient temperature ranging from 9 to $16.5{ }^{\circ} \mathrm{C}$ during the experiment.

\subsection{Short-term experiment}

Exposure to $20 \% \mathrm{O}_{2}$-air saturation for $12 \mathrm{~h}$ led to some major physiological disturbances Fig. 5. Blood pH was stable over the course of the experiment. A significant decrease in plasma total $\mathrm{CO}_{2}$ was observed within $2 \mathrm{~h}$ of exposure. Plasma total $\mathrm{CO}_{2}$ was relatively stable for the next $5 \mathrm{~h}$ and then significantly declined again. A significant increase in plasma osmolarity and chloride concentrations was also observed within $4 \mathrm{~h}$, without major changes up to the end of the experiment. The concomitant increase in plasma lactate showed that fish rapidly resort to anaerobic metabolism (within $4 \mathrm{~h}$ under the experimental conditions of the test). When returned to normoxic water, the recovery capacity of fish was rapid Table 5. Plasma osmolarity and total $\mathrm{CO}_{2}$ were returned to initial levels (pre-exposure conditions) $1 \mathrm{~h}$ after the end of the 6-h exposure to the hypoxic condition tested.

\section{Discussion}

This study showed that over a 6-week period, the growth performance of $45 \mathrm{~g}$ turbot was not substantially depressed in the range between 7.6 and $5.7 \mathrm{mg} \mathrm{O}_{2} \mathrm{l}^{-1}$ (100-75\% air saturation). The present work provides additional data on the growth performance of turbot reared under moderate hypoxic conditions, as previous studies focused either on higher oxygen depletion or hyperoxic conditions (Pichavant et al., 2000, 2001; Person-Le Ruyet et al., 2002). It showed that the threshold concentration for significant reduced growth is about 5-5.5 $\mathrm{mg} \mathrm{O}_{2} \mathrm{l}^{-1}$ in juveniles of turbot. Under rearing conditions and exposure duration similar to those used in this study, it has previously been shown that in 115 and $70 \mathrm{~g}$ turbot, the mass increase was $20 \%$ and $30 \%$ lower at 5 and $4.5 \mathrm{mg} \mathrm{O}_{2} \mathrm{l}^{-1} \mathrm{O}_{2}$, respectively (Pichavant et al., 2000, 2001). Despite the fact that direct comparison with other species is difficult due to differences in experimental conditions, feeding procedures and fish size, growth has been reported to become dependent on $\mathrm{O}_{2}$ concentrations below 4-5 $\mathrm{mg} \mathrm{l}^{-1}$ in most freshwater species (Brett and Blackburn, 

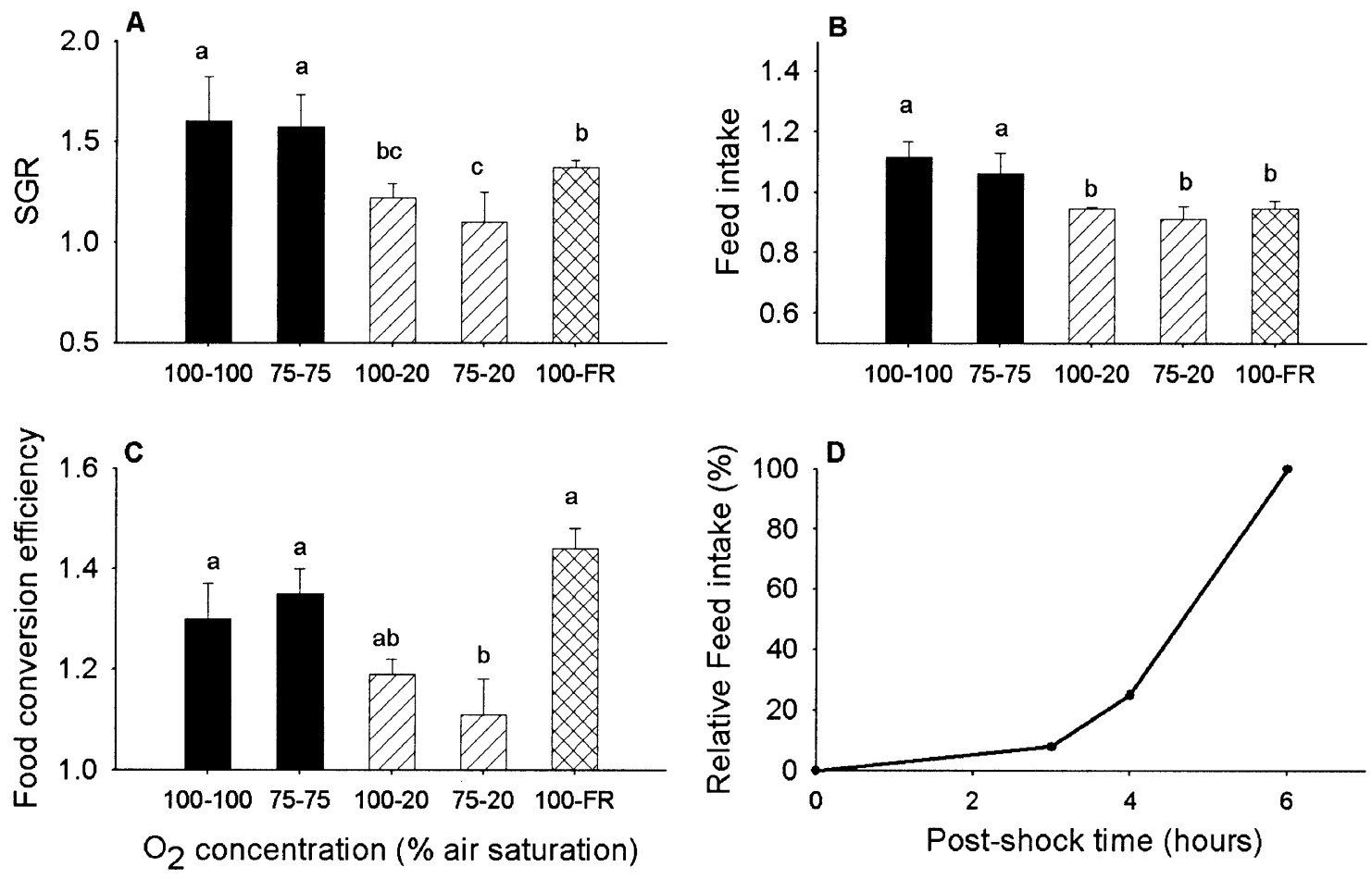

Fig. 3. Day 0-41 SGR (A), FI (B) and FCE (C) related to the five oxygen conditions tested (see Fig. 2legend) and (D) relative FI versus feeding time (hours) after the hypoxic shock. Black bar, constant $\mathrm{O}_{2}$ concentrations; dashed bar, hypoxic shocks; crossed bars, normoxic group feed restricted.

1981). In turbot, the threshold concentration for reduced growth is apparently higher, while among farmed fish species, rainbow trout seems to be the less tolerant species to oxygen depletion (Pedersen, 1987). Experimental results are in agreement with field observations reporting that most fish species select dissolved oxygen regimes $>5 \mathrm{mg}^{-1}$ (Wannamaker and Rice, 2000).

This study showed that turbot responded to repetitive hypoxic shocks (exposure to $1.5 \mathrm{mg} \mathrm{O}_{2} \mathrm{l}^{-1}$ for $1 \mathrm{~h}$, five times per week) by a marked decrease in growth performance compared to stable oxygen conditions having similar weekly mean $\mathrm{O}_{2}$ levels. By considering regular hypoxic shocks as $\mathrm{O}_{2}$ oscillations of high magnitude, these results are in agreement with observed adverse effects of oscillating $\mathrm{O}_{2}$ concentration compared to stable concentrations (Brett, 1979; Taylor and Miller, 2001). The apparent discrepancy between results obtained in seabass juveniles by Thetmeyer et al. (1999) may be partly explained by differences in experimental procedure (small groups of fish, 4-6 fish per 1751 tank; $\mathrm{O}_{2}$ concentrations oscillating between $40 \%$ and $86 \%$ saturation with a period of $12 \mathrm{~h}$ ). Turbot reared in normoxic and moderate hypoxic water responded similarly to repetitive hypoxic shocks in terms of mass increase, and the relative decrease in SGR over a 6 -week period was $23 \%$ and $32 \%$, respectively.

Table 2

Blood plasma and haematological parameters under different $\mathrm{O}_{2}$ concentrations. Data are means \pm S.E. per $\mathrm{O}_{2}$ concentration (duplicated tanks) for five sampling dates (day 2, 6, 13, 28 and 41;n=16×5) except for haematological parameters (days 2 and $41 ; n=16 \times 2$ ) and lactate (days $41 ; n=16$ ). NS $=$ no significant differences $(P>0.05)$

\begin{tabular}{|c|c|c|c|c|c|}
\hline $\mathrm{O}_{2}$ concentrations ( $\%$ air saturation) & $100-100$ & $75-75$ & $100-20$ & $75-20$ & \\
\hline Osmolarity $\left(\mathrm{mOsm} \mathrm{l}^{-1}\right)$ & $321 \pm 6$ & $323 \pm 6$ & $321 \pm 6$ & $322 \pm 6$ & NS \\
\hline Chloride $\left(\mathrm{mmol} \mathrm{l}^{-1}\right)$ & $141 \pm 2$ & $142 \pm \quad 2$ & $141 \pm 2$ & $142 \pm \quad 2$ & NS \\
\hline Sodium $\left(\mathrm{mmol} \mathrm{l}^{-1}\right)$ & $162.0 \pm 2.5$ & $164.5 \pm 2.4$ & $164.9 \pm 2.4$ & $164.9 \pm 2.3$ & NS \\
\hline Potassium $\left(\mathrm{mmol} \mathrm{l}^{-1}\right)$ & $3.8 \pm 0.9$ & $3.8 \pm 0.9$ & $3.9 \pm 0.9$ & $3.8 \pm 0.9$ & NS \\
\hline Total $\mathrm{CO}_{2}\left(\mathrm{mmol} \mathrm{l}^{-1}\right)$ & $7.4 \pm 0.2$ & $6.8 \pm 0.2$ & $7.4 \pm 0.2$ & $6.8 \pm 0.2$ & NS \\
\hline Lactate $\left(\mathrm{mmol} \mathrm{l}^{-1}\right)$ & $0.5 \pm 0.0$ & $0.5 \pm 0.0$ & $0.4 \pm 0.1$ & $0.4 \pm 0.0$ & NS \\
\hline Glucose $\left(\mathrm{mmol} \mathrm{l}^{-1}\right)$ & $2.9 \pm 0.1$ & $2.6 \pm 0.1$ & $2.8 \pm 0.1$ & $2.7 \pm 0.1$ & NS \\
\hline Cortisol (ng ml ${ }^{-1}$ ) & $6.8 \pm 1.0$ & $7.4 \pm 1.2$ & $10.1 \pm 1.7$ & $7.3 \pm 1.2$ & NS \\
\hline Blood pH & $7.69 \pm 0.01$ & $7.67 \pm 0.01$ & $7.69 \pm 0.01$ & $7.71 \pm 0.01$ & NS \\
\hline Haematocrit (\%) & $17 \pm \quad 1$ & $17 \pm \quad 1$ & $16 \pm 1$ & $17 \pm \quad 1$ & NS \\
\hline Haemoglobin $\left(\mathrm{g} \mathrm{dl}^{-1}\right)$ & $3.2 \pm 0.2$ & $3.2 \pm 0.2$ & $3.0 \pm 0.2$ & $3.2 \pm 0.2$ & NS \\
\hline Erythrocyte $\left(10^{6} \mathrm{ml}^{-1}\right)$ & $1.40 \pm 0.02$ & $1.41 \pm 0.02$ & $1.40 \pm 0.02$ & $1.43 \pm 0.02$ & NS \\
\hline
\end{tabular}


Table 3

Time to mortality under severe hypoxic condition (20\% air saturation) in starved and fed turbot pre-conditioned to various $\mathrm{O}_{2}$ treatments LT20 and LT50 (lethal time for $20 \%$ and $50 \%$ of the population) estimated from survival curves. Statistical results are given in the text

\begin{tabular}{llllll}
\hline & \multicolumn{5}{c}{$\begin{array}{l}\text { Pre-treatment } \mathrm{O}_{2} \text { concentrations } \\
(\% \text { air saturation) }\end{array}$} \\
& & $100-100$ & $75-75$ & $100-20$ & $75-20$ \\
\hline LT20 $(\mathrm{min})$ & Starved & 1065 & 1230 & 1125 & 1275 \\
& Fed & 765 & 765 & 729 & 885 \\
LT50 (min) & Starved & 1455 & 1620 & 1545 & 1650 \\
& Fed & 1005 & 1008 & 1035 & 1155
\end{tabular}
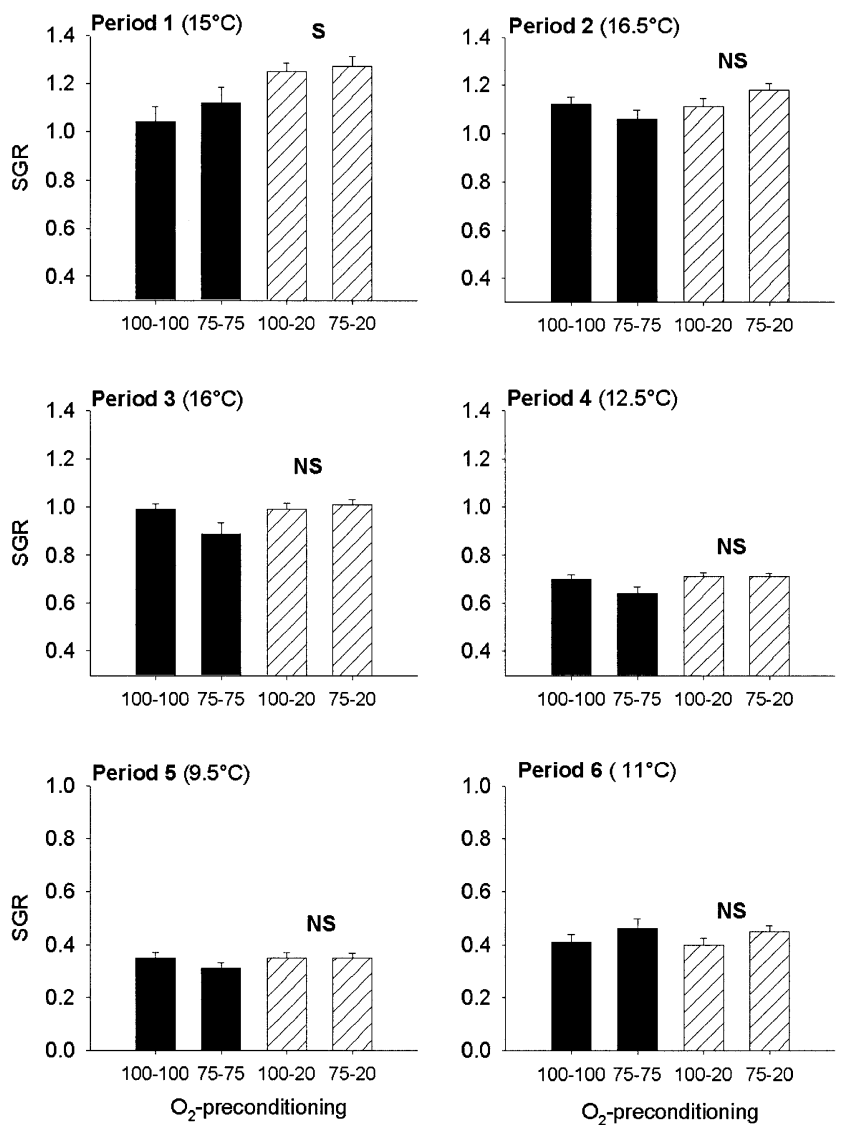

Fig. 4. SGR related to $\mathrm{O}_{2}$ pre-conditioning for different periods of time: period 1, days 0-34; period 2, days 34-91; period 3, days 91-138, period 4, days 138-208; period 5, days 208-283; period 6, days 283-375. Black bar, constant $\mathrm{O}_{2}$ concentrations, and dashed bar, hypoxic shocks groups.
The observed differences in the growth rate of the two hypoxic shock groups will probably increase with exposure duration, as suggested by growth curve slopes.

Differences in turbot mass increase between repeated hypoxic shocks and stable oxygen concentration having a similar weekly mean may be explained by differences in both FI and feed efficiency. When exposed to hypoxic shocks, fish ate less than corresponding groups: $14 \%$ and $18 \%$ less than in normoxic and moderate hypoxic water, respectively. It has previously been shown that in turbot reared under adverse environmental conditions (oxygen depletion or ammonia accumulation), growth decrease was primarily explained by a decrease in FI (Person-Le Ruyet et al., 1997; Pichavant et al., $2000,2001)$. In turbot farms, FI is also affected by environmental conditions, for example, by changes in $\mathrm{O}_{2}$ concentration (Mallekh and Lagardère, 2002). Fish actually possess the sensory mechanisms required for rapid detection of changes in $\mathrm{O}_{2}$ concentration (Burleson et al., 2001). Feeding adjustments are known to be primary behavioural adaptations to hypoxic conditions that allow fish to save energy, as search for food, digestion and assimilation are major components of the energy budget of fish (Brett and Groves, 1979; Kramer, 1987; Jobling, 1994). In this study, feeding was stopped during the hypoxic shocks, but fish rapidly (within $6 \mathrm{~h}$ ) recovered the initial appetite. As a result, the experimental procedures used in this study led to moderate disturbances in FI of fish exposed to repeated hypoxic shocks compared to sustained $\mathrm{O}_{2}$ concentrations: over a 1-week period, only two meals out of 14 were declined by fish.

Apparent FCE was lower when fish were exposed for 6 weeks to repeated hypoxic shocks, with differences dependent on $\mathrm{O}_{2}$ concentrations ( $8 \%$ and $18 \%$ in moderate hypoxic and normoxic water, respectively). Such an adverse effect on feed efficiency has been previously reported in turbot during acclimation to hypoxic conditions but not for long-term exposure to sustained $\mathrm{O}_{2}$ concentrations ranging from 3.5 to $5 \mathrm{mg}^{-1}$ (Pichavant et al., 2001). It may indicate a higher capacity of turbot to adapt to constant environmental conditions than to fluctuating conditions. This finding is confirmed by differences found in growth performance in normoxic water between fish exposed to repeated hypoxic shock and fed to satiation and those feed restricted: mass increase was 7\% lower and FCE tended to be lower. Even under constant oxygen depletion conditions, the discrepancy between feeding procedures used in available studies does not allow any reliable comparison between species as discussed in Pichavant et al. (2001).

The physiological status of turbot was unaffected by repeated hypoxic shocks during the time course of the experi-

Table 4

$P$ values from statistical analysis of SGR results following $\mathrm{O}_{2}$ pre-conditioning

\begin{tabular}{llllll}
\hline & Period 1 & Period 2 & Period 3 & Period 4 & Period 5 \\
\hline Hypoxic shock & $0.610^{-3}$ & 0.084 & 0.043 & 0.102 & 0.134 \\
$\mathrm{O}_{2}$ levels & 0.324 & 0.620 & 0.172 & 0.080 & 0.902 \\
$\mathrm{O}_{2}$ shock $\times \mathrm{O}_{2}$ levels & 0.438 & 0.045 & 0.029 & 0.070 & 0.144 \\
\hline
\end{tabular}



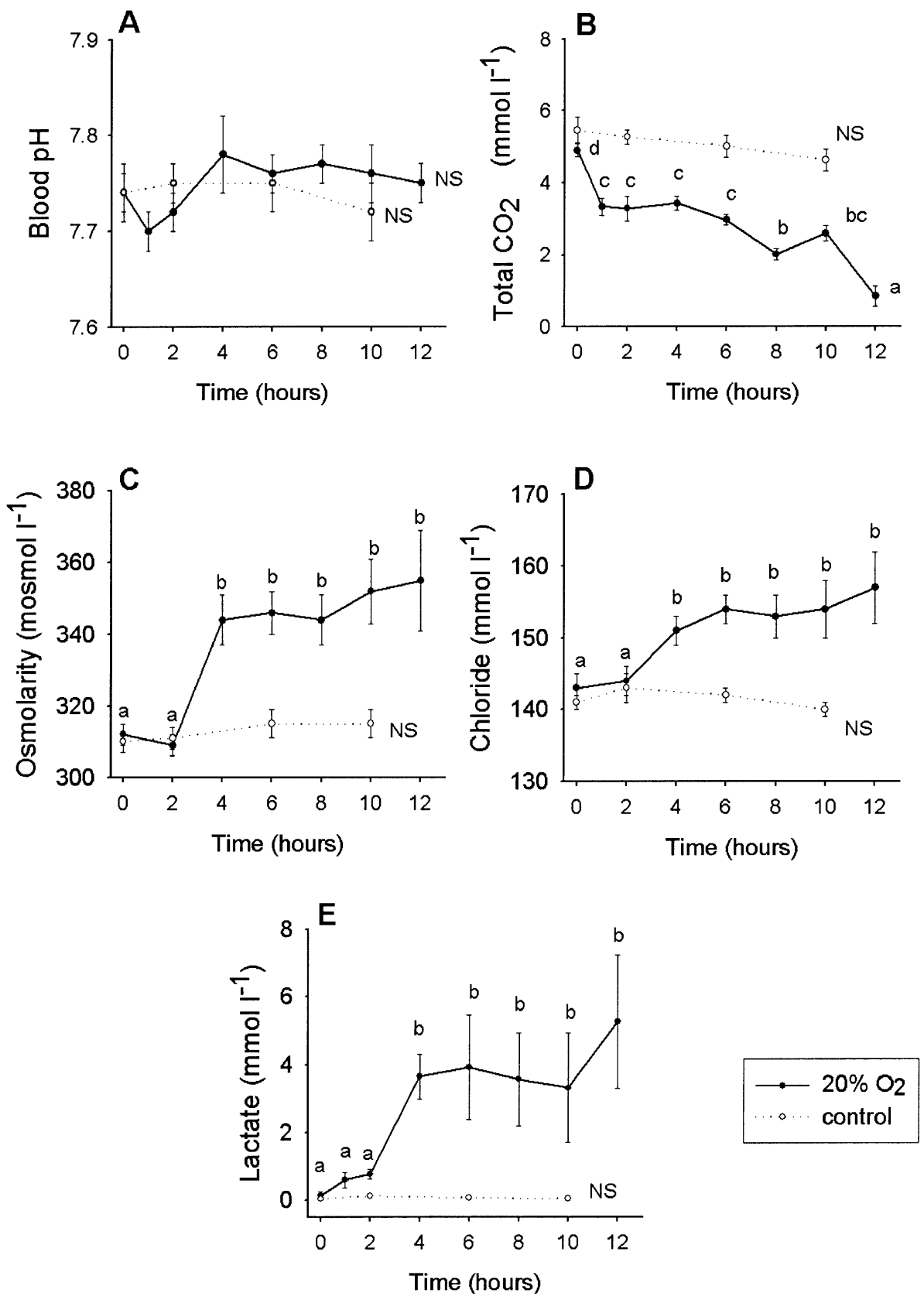

Fig. 5. Changes with time in blood $\mathrm{pH}(\mathrm{A})$, total plasma $\mathrm{CO}_{2}$ (B), plasma osmolarity (C), plasma chloride concentration (D) and plasma lactate (E) in turbot exposed for $12 \mathrm{~h}$ to constant $\mathrm{O}_{2}$ concentration of $20 \%$ air saturation.

ment, at least when measurements occurred $3 \mathrm{~d}$ after the last hypoxic shock. There was no cumulative effect of hypoxic shocks and no sign of stress or anaemia in fish. The physiological parameters measured showed that turbot can adapt rapidly (within $2 \mathrm{~d}$ ) and effectively to the different $\mathrm{O}_{2}$ conditions that did not induce any severe prolonged food restriction. In previous studies (Pichavant et al., 2000, 2001), it has been shown that exposure to constant $\mathrm{O}_{2}$ concentrations of $3.2-3.5 \mathrm{mg} \mathrm{l}^{-1}$, leading to a $50 \%$ decrease in FI, had no effect on hydromineral balance, acid-base status and haematological parameters, and basal $\mathrm{O}_{2}$ consumption was not dependent on $\mathrm{O}_{2}$ concentrations. To our knowledge, few data concerning physiological disturbances under $\mathrm{O}_{2}$-oscillation conditions are available in the literature. In southern flounder juveniles (55-65 mm TL), Taylor and Miller (2001) have shown respiratory adjustments in routine oxygen consumption, ventilation rates and haematocrit levels under $\mathrm{O}_{2}$ oscillations between 2.8 and $6.2 \mathrm{mg} \mathrm{l}^{-1}$ during day light cycle, without reference to feeding parameters.

Under the experimental conditions used in this study, acclimation of turbot to repeated hypoxic shocks extended, slightly but significantly, the survival time when exposed to a 
Table 5

Changes with time of some physiological indicators during a $7 \mathrm{~h}$ recovery period following exposure to severe hypoxic condition (20\% air saturation) for $6 \mathrm{~h}$ Data are means \pm S.E. $(n=8$ per sampling date). Letters following means indicate statistical differences between exposure duration. Means not sharing a common letter are significantly different $(P<0.05)$. NS $=$ no significant differences

\begin{tabular}{|c|c|c|c|c|}
\hline Time (h) & Blood pH & Total $\mathrm{CO}_{2}\left(\mathrm{mmol} \mathrm{l}^{-1}\right)$ & Osmolarity (mOsmol 1-1) & $\mathrm{Cl}^{-}\left(\mathrm{mmol} \mathrm{l}^{-1}\right)$ \\
\hline-6 (pre-exposure) & $7.69 \pm 0.02$ & $6.2 \pm 0.4 \mathrm{a}$ & $315 \pm 1 \mathrm{a}$ & $142 \pm 1$ \\
\hline 0 (end exposure) & $7.67 \pm 0.01$ & $2.8 \pm 0.2 b$ & $324 \pm 1 b$ & $140 \pm 1$ \\
\hline 1 (recovery onset) & $7.64 \pm 0.01$ & $5.6 \pm 0.2 \mathrm{a}$ & $319 \pm 3 a$ & $141 \pm 2$ \\
\hline 4 & $7.70 \pm 0.02$ & $6.0 \pm 0.3 \mathrm{a}$ & $314 \pm 2 a$ & $140 \pm 1$ \\
\hline \multirow[t]{2}{*}{7 (end of recovery) } & $7.73 \pm 0.03$ & $5.5 \pm 0.4 \mathrm{a}$ & $316 \pm 3 a$ & $142 \pm 1$ \\
\hline & NS & $P<10^{-6}$ & $P=0.002$ & NS \\
\hline
\end{tabular}

longer hypoxic shock of similar magnitude. Survival benefit averaged $30 \mathrm{~min}$. In comparison, fish response to survival challenge was highly dependent on the nutritional status of the fish: first mortality was observed after $4 \mathrm{~h}$ in fed turbot and $8 \mathrm{~h}$ later in starved fish, while the kinetic of mortality was the same. Differences in survival response to an acute additional stress between fed and starved fish may be related to the energetic expenditure required for the digestion and assimilation of food (Brett and Groves, 1979). In zebra fish, Danio rerio, acclimation to $10 \%$ air saturation for $48 \mathrm{~h}$ significantly extended survival time during more severe hypoxia (5\% air saturation) compared to individuals with no prior hypoxic exposure (Rees et al., 2001). The magnitude of the acclimation effect depended on sex and season, suggesting that hypoxia tolerance in zebra fish (and probably in other fish species) is modulated by genetic and/or environmental factors; as a result, comparisons within and between species are difficult.

Fish capacity to fully recover from an additional severe hypoxic shock was very high. When surviving fish were held in normoxic water, survival was maximum over a 1-year period. The significant growth improvement, initially observed in fish acclimated to regular hypoxic shocks compared to individuals held under stable similar $\mathrm{O}_{2}$ concentrations, may result from compensatory growth following a chronic stress. In this study, compensatory effect on growth was only observed for a short time. It was of low magnitude, probably partly as the growth test started after a recovery period of 1 month and not immediately at the end of the $\mathrm{O}_{2}$-pre-conditioning period. Compensatory growth has been reported in fish previously exposed to different stressful environmental conditions causing a long-term food privation or in fish re-fed after a period of starvation or a period of feed restriction (Dobson and Holmes, 1984; Jobling et al., 1999). Over a 1-year period, SGR was acceptable under the conditions of the grow-out test: 0.64 and 0.70 depending on $\mathrm{O}_{2}$ pre-conditioning and in the same range as in a reference group reared under usual conditions, 0.66 , during the same period. This study showed that the growth potential of turbot is not necessarily definitively affected by repetitive hypoxic shocks leading to $25-30 \%$ loss in growth over a 6-week period, even when fish are exposed to an additional hypoxic shock causing $50 \%$ mortality.

Turbot exposure to $20 \% \mathrm{O}_{2}$-air saturation for 6 or $12 \mathrm{~h}$ followed by a return to normoxic water showed that fish can recover rapidly from major disturbances in acid-base status and ionic balance induced by hypoxic conditions. The progressive decrease in plasma total $\mathrm{CO}_{2}$ may result from respiratory adjustments required to maintain $\mathrm{O}_{2}$ consumption stable. The increase in the amplitude and frequency of ventilation has been described by Maxime et al. (2000) in large turbot in response to progressive oxygen depletion. The concomitant increase in plasma lactate (metabolic lactic acidosis) efficiently compensated for respiratory alkalosis and blood $\mathrm{pH}$ was maintained stable. Major changes in osmolarity and $\mathrm{Cl}^{-}$concentration indicated that ionic exchanges through the gill were highly affected. The increase in plasma $\mathrm{Cl}^{-}$may be related to $\mathrm{HCO}_{3}{ }^{-}$decrease, as gill acid-base flux $\left(\mathrm{H}^{+}\right.$and $\left.\mathrm{HCO}_{3}{ }^{-}\right)$is usually coupled to ion exchanges $\left(\mathrm{Cl}^{-}\right.$and $\mathrm{Na}^{+}$). Marked increase in plasma lactate showed that fish resorted to anaerobic metabolism within $4 \mathrm{~h}$, as has previously been observed in turbot under similar hypoxic conditions (Maxime et al., 2000) and in another flat fish species, sole (Solea solea) (Dalla Via et al., 1998; Van den Thillart et al., 1994). Survival was over $95 \%$ at the end of the 12 -h test, which is in agreement with the survival challenge test results. In groups exposed to $20 \% \mathrm{O}_{2}$-air saturation for $6 \mathrm{~h}$, plasma total $\mathrm{CO}_{2}$ and osmolarity returned to pre-exposure levels $1 \mathrm{~h}$ after the end of hypoxic exposure. The high capacity of turbot to recover from major physiological disturbances helped in explaining why fish growth potential is not irreversibly affected by an acute hypoxic shock. It does not mean that turbot will be as tolerant as reference fish when exposed to other environmental stressors (e.g. ammonia) or to cumulative acute stress over a long period.

\section{References}

Blancheton, J.P., 2000. Developments in recirculation systems for Mediterranean fish species. Aquacult. Eng. 22, 17-31.

Brett, J.R., 1979. Environmental factors and growth. In: Hoar, W.S., Randall, D.J., Brett, J.R. (Eds.), Bioenergetics and Growth. Fish Physiology, vol. VIII. Academic Press, New York, pp. 599-675.

Brett, J.R., Blackburn, J.M., 1981. Oxygen requirements for growth of young coho (Oncorhynchus kisutch) and sockeye (O. nerka) salmon at $15^{\circ}$ C. Can. J. Fish. Aquat. Sci. 38, 399-404.

Brett, J.R., Groves, T.D.D., 1979. Physiological energetics. In: Hoar, W.S., Randall, D.J., Brett, J.R. (Eds.), Bioenergetics and Growth. Fish Physiology, vol. VIII. Academic Press, New York, pp. 279-352.

Burleson, M.L., Wilhelm, D.R., Smatresk, N.J., 2001. The influence of fish size on the avoidance of hypoxia and oxygen selection by largemouth bass. J. Fish Biol. 59, 1336-1349. 
Dalla Via, J., Van den Thillart, G., Cattani, O., Cortesi, P., 1998. Behavioural responses and biochemical correlates in Solea solea to gradual hypoxic exposure. Can. J. Zool. 76, 2108-2113.

Dobson, S.H., Holmes, R.M., 1984. Compensatory growth in the rainbow trout. Salmo gairdneri Richardson. J. Fish Biol. 25, 649-656.

Foss, A., Evensen, T.H., Oiestad, V., 2002. Effects of hypoxia and hyperoxia on growth and food conversion efficiency in the spotted wolffish Anarhichas minor (Olafsen). Aquacult. Res. 33, 437-444.

Fostier, A., Billard, R., Breton, B., Legendre, M., Marlot, S., 1982. Plasma II-exotestosterone and gonadotropin during the beginning of spermiation in rainbow trout (Salmo gairdneri R. Gen. Comp. Endocrinol. 46, 428-434.

Gaumet, F., Boeuf, G., Sévère, A., Le Roux, A., Mayer-Gostan, N., 1995. Effects of salinity on the ionic balance and growth of juvenile turbot. J. Fish Biol. 47, 865-876.

Jobling, M., 1994. Fish Bioenergetics, vol. XIV. Chapman and Hall, London.

Jobling, M., Koskela, J., Winberg, S., 1999. Feeding and growth of white fish fed restricted and abundant rations: influences on growth heterogeneity and brain serotonergic activity. J. Fish Biol. 54, 437-449.

Kramer, D.L., 1987. Dissolved oxygen and fish behavior. Environ. Biol. Fish. 18, 81-92.

Mallekh, R., Lagardère, J.P., 2002. Effects of temperature and dissolved oxygen concentration on the metabolic rate of the turbot and the relationship between metabolic scope and feeding demand. J. Fish Biol. 60, 1105-1115.

Maxime, V., Pichavant, K., Boeuf, G., Nonnotte, G., 2000. Effects of hypoxia on respiratory physiology of turbot, Psetta maxima. Fish. Physiol. Biochem. 22, 51-59.

Pedersen, C.L., 1987. Energy budgets for juvenile rainbow trout at various oxygen concentrations. Aquaculture 62, 289-298.

Person-Le Ruyet, J., Baudin-Laurencin, F., Devauchelle, N., Métailler, R., Nicolas, J.L., Robin, J., Guillaume, J., 1991. Culture of turbot (Scophthalmus maximus). In: McVey, J.P. (Ed.), Finfish Aquaculture. CRC Handbook of Mariculture, vol. II. CRC Press, Boca Raton, pp. 77-82.
Person-Le Ruyet, J., Galland, R., Le Roux, A., Chartois, H., 1997. Chronic ammonia toxicity in juvenile turbot (Scophthalmus maximus). Aquaculture $154,155-171$.

Person-Le Ruyet, J., Pichavant, K., Vacher, C., Le Bayon, N., Sévère, A., Bœuf, G., 2002. Effects of oxygen supersaturation on growth and metabolism in juvenile turbot (Scophthalmus maximus). Aquaculture 205, 373-383.

Pichavant, K., Person-Le Ruyet, J., Le Bayon, N., Sévère, A., Le Roux, A., Quéméner, L., Maxime, V., Nonnotte, G., Bœuf, G., 2000. Effects of hypoxia on growth and metabolism of juvenile turbot. Aquaculture 188, $103-114$.

Pichavant, K., Person-Le Ruyet, J., Le Bayon, N., Sévère, A., Le Roux, A., Bœuf, G., 2001. Comparative effects of long-term hypoxia on growth, feeding and oxygen consumption in juvenile turbot and European seabass. J. Fish Biol. 59, 875-883.

Rees, B.B., Sudradjat, F.A., Love, J.W., 2001. Acclimation to hypoxia increases survival time of zebrafish, Danio rerio, during lethal hypoxia. J. Exp. Zool. 289, 266-272.

Taylor, J.C., Miller, J.M., 2001. Physiological performance of juvenile southern flounder, Paralichthys lethostigma (Jordan and Gilbert, 1984), in chronic and episodic hypoxia. J. Exp. Mar. Biol. Ecol. 258, 195-214.

Thetmeyer, H., Waller, U., Black, K.D., Inselmann, S., Rosenthal, H., 1999. Growth of European sea bass (Dicentrarchus labrax L.) under hypoxic and oscillating oxygen conditions. Aquaculture 174, 355-367.

Van den Thillart, G., Dalla Via, J., Vitali, G., Cortesi, P., 1994. Influence of long-term hypoxia exposure on the energy metabolism of Solea solea. I. Critical $\mathrm{O}_{2}$ levels for aerobic and anaerobic metabolism. Mar. Ecol. Prog. Ser. 104, 109-117.

Wannamaker, C.M., Rice, J.A., 2000. Effects of hypoxia on movements and behavior of selected estuarine organisms from the southeastern United States. J. Exp. Mar. Biol. Ecol. 249, 145-163. 